\title{
STRATEGI PENINGKATAN KEMANDIRIAN BELAJAR MAHASISWA PENDIDIKAN BAHASA ARAB DI ERA REVOLUSI INDUSTRI 4.0
}

\author{
(Strategy For Self-Regulated Learning Improvement in Arabic Language Education \\ Students in The Era of The Industrial Revolution 4.0)
}

\author{
Saproni Muhammad Samin*) yenni Yunita**) Ismail Akzam***) \\ Susanto $\left.{ }^{* * * *}\right)$ Fauzi Azmi*****) \\ safroni.ahmad@edu.uir.ac.id
}

$*, * *, * * *)$ Dosen Universitas Islam Riau
$\left.{ }^{* * * *, * * * * *}\right)$ Mahasiswa Prodi PBA Universitas Islam Riau

\begin{abstract}
This research is qualitative research using a descriptive approach. Data collection techniques in this study using Interview Techniques, Documentation, and Literature Studies. The systematics of strategy formulation refers to five stages. These stages include: (1) Environmental identification (2) Conducting internal and external environmental analysis by measuring strengths and weaknesses as well as opportunities and threats, (3) Formulating key success factors of strategies designed based on the previous analysis, (4) Determining measurable goals and targets, evaluating various alternative strategies by considering the available resources and external conditions faced, (5) Selecting the most appropriate strategy to achieve short-term and long-term goals. This study shows the results of several strategies to increase learning Self-Regulated Learning for Arabic Language Education students at the Universitas Islam Riau as follows; 1) Using a Student-Centered learning (SCL) approach in learning, 2) Using a Net-centric approach in learning media, 3) Building student awareness about Self-Regulated Learning on an ongoing basis, 4) Using E-learning applications that can encourage and stimulate students carry out Self-Regulated Learning, 5) Coordinate between Permanent Lecturers of Study Programs in the formulation of Semester Learning Plans for the core courses of study programs, 6) Create an Arabic language environment, 7) Conduct reward programs for student achievements, 8) There is lecturer guidance for students who will compete.
\end{abstract}

Keywords: Arabic Language Education, Industrial Revolution 4.0, Self-Regulated Learning, Students, Strategy.

\section{PENDAHULUAN}

Era Revolusi Industri 4.0 (RI 4.0) yang juga sering disebut sebagai Revolusi Digital selain juga sering disebut sebagai Era Disrupsi (Risdianto, 2019), telah merubah paradigma berfikir manusia di semua aspek kehidupan, tidak terkecuali dunia pendidikan. Disrupsi adalah sebuah istilah yang berarti terlepas dari akarnya, kemudian diartikan sebagai era inovasi secara fundamental. Disebut demikian karena perubahan yang terjadi adalah perubahan sangat mendasar dalam kehidupan masyarakat secara masif (Kasali dalam Risdianto, 2019). Karakteristik RI 4.0 atau Era Disrupsi dapat disebut dengan istilah VUCA; Volality yaitu perubahan yang cepat, masif dan sulit ditebak, uncertainly yaitu perubahan yang menyebabkan ketidakpastian, Complexity yaitu hubungan antar faktor perubahan yang sangat komplek, dan Ambiguity yaitu lahirnya ambiguitas karena arah perubahan yang kurang jelas (Ristekdikti, 2018). RI 4.0 harus disikapi secara positif dan dinamis, karena perubahan paradigma 
sebagai tuntutan era baru ini adalah sebuah konsekuensi logis dan natural. Gagal dalam mensikapi tuntutan perubahan RI 4.0, gagal dalam menghubungkan diri dengan dunia luar, meskipun tidak harus latah dengan serta merta harus meninggalkan nilai-nilai kearifan lokal (local wisdom) sebagai karakter yang tetap harus dipertahankan (Saproni, 2018). Era RI 4.0 telah benarbenar merubah paradigma Pendidikan untuk berfokus pada Knowledge Production dan Innovation Applications Of Knowlwdge (Zubaidah, 2018) sebagaimana pembelajan yang berorientasi pada Higher Order Thinking Skills (HOTS) (Mukhlis and Tohir, 2019), hal ini menuntut adanya kemampuan berpikir kreatif dan inovatif.

Pembelajaran Bahasa Arab di tingkat Perguruan Tinggi di RI 4.0, juga menuntut beberapa hal di antaranya adalah keselarasan pencapaian visi RI 4.0 dengan pendekatan Heutagogi dalam pendidikan (Ridha, 2018), yaitu memperlakukan mahasiswa tidak sekedar sebagai orang dewasa secara psikologis, namun sebagai orang yang mempunyai otonomi belajar, menanamkan semangat belajar kepada mahasiswa dengan semangat sebagai pembelajar seumur hidup dan selanjutnya adalah menumbuhkan kemandirian belajar bagi mahasiswa sebagai modal dasar untuk tercapainya kompetensi utama (Samin, 2019). Kemandirian belajar selain ia adalah tuntutan ajaran agama (Saproni, 2017), ia juga sebagai kata Kunci yang menghubungkan tiga kenyataan yang berlaku dewasa ini; fenomena RI 4.0, pendekatan Heutagogi dalam dunia pendidikan - sebagai kelanjutan dari pendekatan Pedagogi kemudian Andragogi - dan pendekatan postmethod dalam bidang pengajaran bahasa sebagai bahasa asing (Samin, 2019) (Wahab, 2015). Berikut ini beberapa indikator kemandirian dalam belajar bahasa yang dikemukakan oleh Johnson dalam Asrori (2012), yaitu; (1) Mempunyai kemauan dan keberanian untuk menebak/menerka makna, (2) Mempunyai kemauan kuat untuk praktik berkomunikasi atau belajar dari komunikasi, (3) Berani mengambil resiko dan tidak takut salah dalam rangka belajar dan berkomunikasi, (4) Agar bisa fokus dalam komunikasi, ia memberikan perhatian kepada bentuk kebahasan sebelum melakukan tindak komunikasi, (5) Mempraktikan bahasa yang dipelajari, (6) Memonitor tuturan sendiri dan tuturan mitra tutur, (7) Memperhatikan keberterimaan tuturannya oleh mitra tutur, (8) Lebih memperhatikan makna dalam menghadapi tuturan mitra tutur.

Pandemi Covid-19 yang dialami semua penduduk planet bumi ini, telah menjadikan dunia pendidikan beradaptasi dalam pola pembelajarannya terhadap peserta didik, yaitu pembelajaran melalui Daring (dalam jaringan), sekaligus menegaskan betapa pentingnya pembelajaran berbasis internet (NetCentric) di saat manusia mengharuskan melakukan jarak sosial (social distancing). pasca covid-19 ini, paradigma pembelajaran dengan berbasis internet, mendapatkan momentumnya untuk menjadi sebuah kesadaran kolektif, meskipun RI 4.0 telah lebih dulu menuntut masyarakat mempunyai kesadaran tersebut, namun kegagapan di satu titik dan ketidaksiapan di titik yang lain betul-betul melahirkan kegamangan, namun covid-19 mempunyai sisi positifnya dalam hal melahirkan kesadaran kolektif ini.

Pembelajaran Bahasa Arab juga tidak terlepas dari kebutuhannya terhadap kemandirian belajar mahasiswa dalam 
mensikapi semua perubahan yang terjadi dilingkungan dan di zaman mereka hidup sekarang, seperti yang telah diterangkan di atas. Mata kuliah-mata kuliah di program studi (Prodi) Pendidikan Bahasa Arab (PBA) di Universitas Islam Riau (UIR) diklasifikasikan kedalam mata kuliah keterampilan berbahasa (Maharoh Lughowiyah) dan mata kuliah keilmuan bahasa Arab, pendidikan dan Keguruan. Mata kuliah keterampilan berbahasa adalah mata kuliah yang bertumpu pada target penguasaan empat keterampilan; istima' (writing), kalam (speaking), qiro'ah (reading) dan kitabah (writing). sedangkan mata kuliah keilmuan kebahasaan arab, pendidikan dan keguruan adalah mata kuliah yang bertumpu pada target penguasaan teori-teori kebahasaan, kependidikan dan pembekalan mahasisawa menjadi seorang pendidik.

Dalam observasi peneliti, kemandirian belajar mahasiswa PBA UIR belum begitu menggembirakan. Hal tersebut bisa dilihat misalnya dalam hal ketergantungan mereka kepada dosen dalam proses pembelajaran dikelas, minimnya kemampuan mereka dalam mengembangkan pemahaman materi perkuliahan dengan merujuk kepada berbagai literatur pendukung yang berasal dari berbagai sumber dan lain-lain.

Berdasarkan latar belakang di atas maka rumusan masalah dalam penelitian ini adalah: Bagaimana strategi peningkatan kemandirian belajar mahasiswa Pendidikan Bahasa Arab di Era Revolusi Industry 4.0. Berdasarkan rumusan masalah di atas, maka tujuan dari penelitian ini adalah: merumuskan strategi peningkatan kemandirian belajar mahasiswa Pendidikan Bahasa Arab di Era Revolusi Industry 4.0.

\section{METODE PENELITIAN}

Penelitian ini merupakan penelitian kualitatif dengan menggunakan pendekatan Deskriptif. Deskriptif tujuannya untuk menjelaskan atau mendeskripsikan suatu peristiwa, keadaan, objek apakah orang, atau segala sesuatu yang terkait dengan variabel-variabel yang bisa dijelaskan baik menggunakan angka-angka maupun kata-kata (Punaji, 2013). Dalam merumuskan strategi, peneliti menggunakan teori yang dikemukakan Hariadi (2004) sebagai tahapan-tahapan yang akan dilalui dalam penelitian ini. Tahapan-tahapan tersebut meliputi: (1) identifikasi lingkungan (2) melakukan analisis lingkungan internal dan eksternal dengan cara mengukur kekuatan dan kelemahan serta peluang dan ancaman, (3) Merumuskan faktor-faktor ukuran keberhasilan (key success factors) dari strategi-strategi yang dirancang berdasarkan analisis sebelumnya, (4) Menentukan tujuan dan target terukur, mengevaluasi berbagai alternatif strategi dengan mempertimbangkan sumberdaya yang dimiliki dan kondisi eksternal yang dihadapi, (5) Memilih strategi yang paling sesuai untuk mencapai tujuan jangka pendek dan jangka Panjang. Penelitian ini dilakukan di Prodi PBA UIR yang sekaligus sebagai social situation, yaitu sebagai obyek penelitian yang ingin diketahui "apa yang terjadi" di dalamnya (Sugiyono, 2014). Adapun Pengumpulan data dalam penelitian ini dilakukan dengan empat cara, yaitu sebagai berikut: 1) Wawancara. Wawancara dilakukan kepada ketua prodi PBA UIR dan Tim Kurikulum 2021, 2) Dokumentasi. Dokumen yang dimaksud adalah dokumen Lembar Evaluasi Diri (LED) yang disiapkan oleh Fakultas Agama Islam dalam rangka 
persiapan Akreditasi BANPT pada tahun 2020, kurikulum prodi PBA 2017 dan kurikulum PBA 2021 dan dokumendokumen lain yang terkait dengan pengajaran Prodi di PBA-UIR, 3) Library research, yaitu metode dengan menggunakan literatur (kepustakaan), baik berupa buku, catatan, maupun laporan hasil penelitian dari penelitian terdahulu. Analisis data dalam penelitian ini adalah analisis deskriptif, yaitu melakukan sebuah Analisa dari data-data yang telah peneliti kumpulkan pada tahapan pertama sampai dengan tahapan keempat dan mengacu kepada teori-teori yang digunakan. Adapun sistematika perumusan strategi mengacu kepada rumusan target terukur terkait dengan pengembangan strategi peningkatan kemandirian belajar mahasiswa PBA UIR yang terdapat pada langkah keempat.

\section{HASIL DAN PEMBAHASAN Identifikasi Lingkungan}

Dalam melakukan identifikasi lingkungan, peneliti pertama kali menetapkan bahwa yang menjadi cakupan identifikasi lingkungan peneliti menggunakan instrumen wawancara dan dokumentasi dengan ketua prodi dan tim penyusun kurikulum Prodi PBA 2021. Hasil dari wawancara ini mendapatkan informasi bahwa tingkat kemandirian belajar mahasiswa Prodi PBA UIR belum sesuai dengan harapan prodi PBA, dan hasil ini sesuai dengan hasil laporan penelitian internal UIR dari peneliti Sesuai Dengan Kontrak penelitian nomor: 76/KONTRAK/LPPM_UIR/5-2020, yang menunjukan bahwa kemandirian belajar mahasiswa PBA UIR pada level cukup baik dengan persentase $65,9 \%$ dalam skala Likert, meskipun level ini belum sesuai dengan ekspektasi prodi, karena proses belajar mengajar via online di era pandemik covid-19 ini sudah berlangsung selama satu tahun lebih, yang seharusnya lebih tinggi dari sekedar cukup baik.

\section{Melakukan Analisis Lingkungan Internal dan Eksternal dengan Cara Mengukur Kekuatan dan Kelemahan serta Peluang dan Ancaman.}

Dalam rangka menghasilkan analisis lingkungan internal dan eksternal, peneliti menggunakan instrumen pengumpulan data berupa wawancara dengan kaprodi PBAUIR dan dokumentasi berupa mempelajari dokumen berupa dokumen LED (Lembar Evaluasi Diri) yang disusun oleh tim Fakultas Agama Islam, yang disiapkan dalam rangka Akreditasi pertama prodi PBA dari BAN PT pada tahun 2020. Hasil analisis lingkungan ini melahirkan Analisis SWOT (Strength, Weakness, Opportunities, Threats) Prodi.

Merumuskan Faktor-Faktor Ukuran Keberhasilan (Key Success Factors) dari Strategi-strategi yang dirancang berdasarkan Analisis sebelumnya.

Dalam rangka merumuskan faktorfaktor ukuran keberhasilan (key success factor), maka peneliti mengumpulkan data menggunakan instrumen dokumentasi dengan mempelajari dokumen kurikulum PBA 2021 dengan mempelajari Visi, Misi, Tujuan dan Strategi yang telah dirumuskan oleh prodi PBA sebagai ukuran keberhasilan. Selain dari pada itu peneliti juga menggunakan library research untuk mendapatkan standar sukses pembelajaran pada salah satu rumpun inti prodi PBA yaitu kemahiran berbahasa. Untuk ukuran kemahiran berbahasa mengacu kepada rumusan Rusydi Ahmad thuaimah dalam Ahmad (2018), yang terdiri dari 23 standar 
untuk kemahiran mendengar, 23 standar untuk kemahiran berbicara, 23 standar untuk kemahiran membaca, dan 22 standar untuk kemahiran menulis.

\section{Menentukan Tujuan dan Target Terukur, Mengevaluasi Berbagai Alternatif Strategi dengan Mempertimbangkan Sumberdaya yang dimiliki dan Kondisi Eksternal yang dihadapi.}

Pada Langkah keempat dalam pengembangan strategi peningkatan kemandirian belajar mahasiswa PBA peneliti merumuskan sebuah tujuan dan target terukur serta mengevaluasi berbagai alternatif strategi dengan mempertimbangkan sumberdaya yang dimiliki oleh PBA UIR dan kondisi eksternal yang dihadapi. Untuk menentukan tujuan dan target terukur, mengacu kepada data-data yang telah dikumpulkan oleh peneliti pada Langkah pertama, kedua dan ketiga.

Rumusan tujuan Prodi dalam pembelajaran adalah "Terwujudnya lulusan handal dalam bidang Pendidikan Bahasa Arab yang memiliki kemampuan komunikasi bahasa arab tingkat lanjut, berdaya saing di tingkat nasional". Adapun target terukurnya adalah; 1) Mendalam dalam keilmuan kebahasaaraban, kependidikan serta keguruan, 2) Menetapkan standar kemahiran bahasa arab (TOAFL) minimum kepada lulusan PBA FAI UIR dengan skor 500, 3) Melaksanakan Pembelajaran Bahasa Arab dengan pendekatan komunikatif dan telaah turats, sesuai dengan perkembangan keilmuan Pendidikan Bahasa Arab terkini, dan 4) Berprestasi di bidang akademik maupun non-akademik di tingkat Nasional maupun internasional.

Adapun evaluasi strategi peningkatan kemandirian belajar pada kurikulum 2017 adalah sebagai: 1) Matrikulasi. Matrikulasi Bahasa Prodi untuk mahasiswa yang berasal dari sekolah umum cukup membantu, namun belum dilakukan sebuah evaluasi resmi dari prodi PBA dan dalam perkembangannya tidak berjalan secara konsisten, hal ini dikarenakan salahsatunya adalah karena keterbatasan tenaga dan padatnya kegiatan dosen dalam pengembangan kapasitas diri sebagai dosen pemula. 2) Placement Test. Placement test berfungsi untuk memetakan kemampuan mahasiswa, sehingga terpetakan kemampuan kemahiran Bahasa mahasiswa dan menjadi titik tolak treathment (penanganan) untuk setiap mahasiswa, namun dalam perkembangannya hal ini tidak berjalan secara konsisten. 3) Nasyath Thullab (Program Kreativitas Mahasiswa). Nasyath Thulab merupakan kegiatan yang bertujuan menciptakan lingkungan Bahasa Arab di tengah-tengah mahasiswa dengan mengelompokkan mahasiswa pada beberapa kelompok dan di beri tugas untuk menampilkan kegiatan dengan menggunakan Bahasa Arab sebagai Bahasa komunikasinya, namun dalam perjalanannya, kegiatan inipun tidak konsisten hanya beberapa kali diadakan. 4) Grup Whatsapp. Menggunakan media social semisal WA Grup antar mahasiswa dengan menjadikan komunikasi berbahasa Arab, juga belum terealisasi dengan baik, bahkan WA Grup Prodi yang menjadi ajang komunikasi dosen dengan seluruh mahasiswa PBA lintas Angkatan juga belum mengoptimalkan Bahasa Arab sebagai media menyampaikan informasi resmi maupun info-info lain. 5) Pembelajaran via Online. Dalam masa pandemi covid-19 pembelajaran untuk seluruh matakuliah dilakukan secara 
online. Dari survey yang dilakukan prodi PBA di masa covid-19, mayoritas mahasiswa tidak memiliki kesiapan mental yang cukup untuk melakukan pembelajaran secara online.

Memilih Strategi yang Paling Sesuai untuk Mencapai Tujuan Jangka Pendek dan Jangka Panjang.

Dalam rangka menentukan strategi yang paling sesuai untuk mencapai tujuan PBA UIR, peneliti pada Langkah kelima ini, melakukan sebuah Analisa dari datadata yang telah peneliti kumpulkan pada tahapan pertama sampai dengan tahapan keempat. Adapun sistematika perumusan strategi mengacu kepada rumusan target terukur terkait dengan pengembangan strategi peningkatan kemandirian belajar mahasiswa PBA UIR pada mata kuliah kemahiran berbahasa dan keilmuan kependidikan dan keguruan yang terdapat pada langkah keempat. Adapun Rumusan pengembangan Strategi Pengembangan kemandirian belajar mahasiswa PBA adalah sebagai berikut:

1) Menggunakan pendekatan Student-

Centred Learning (SCL) dalam pembelajaran. SCL adalah sebuah pendekatan yang sesuai dengan perkembangan dan tuntutan Revolusi industry 4.0, serta Heutagogy sebagai sebuah pendekatan dalam berinteraksi dengan mahasiswa - lanjutan dari Pedagogy dan Andragogy - menuntut untuk menjadikan peran Dosen adalah sebagai konsultan. Hal ini mengharuskan proses Pendidikan bertumpu pada mahasiswa sampai dengan mereka mampu menentukan tujuan sendiri kenapa mereka harus mempelajari objek tertentu.

2) Menggunakan pendekatan Net-centric dalam media pembelajaran.
Pembelajaran berbasis net bukan berarti peserta didik bisa sekedar akses internet, namun lebih jauh dari pada itu. Net-Centred menuntut mahasiswa untuk menguasai kemampuan membaca big data, tidak gagap dalam berinteraksi dengan berbagai aplikasiaplikasi pembelajaran yang beragam, serta mahasiswa mempunyai dasar untuk mampu membaca bahasa program.

3) Membangun kesadaran mahasiswa tentang kemandirian belajar secara berkesinambungan. Hal ini karena banyak di antara mahasiswa yang masih belum mampu keluar dari pengalaman lama Ketika pendekatan yang digunakan di sekolah menengah adalah pendekatan Teacher-Centred Learning (TCL).

4) Menggunakan aplikasi E-learning yang mendorong mahasiswa melakukan kemandirian belajar. Hal ini dapat diukur salahsatunya dengan kemampuan mahasiswa mengeksplorasi pendapat serta menstimulus mereka memberikan gagasan orisinil terkait topik-topik kajian, seperti menggunakan fitur forum diskusi dalam Moodle, serta tugas-tugas kelas lainnya.

5) Melakukan koordinasi antar Dosen Tetap Prodi Studi (DTPS) dalam perumusan Rencana Pembelajaran Semester (RPS) untuk mata kuliah inti prodi. Hal ini dalam rangka menyatukan persepsi dan ketercapaian target prodi terhadap kompetensi mahasiswa melalui mata kuliah tersebut.

6) Menciptakan Lingkungan Bahasa. Terciptanya lingkungan Bahasa menjadikan mahasiswa terdorong 
untuk menggunakan Bahasa Arab sebagai Bahasa komunikasi.

7) Motivasi berkompetisi. Kemandirian belajar sangat terkait dengan mental siap berkompetisi. Berangkat dari hal ini, mahasiswa perlu didorong, distimulus, dimotivasi serta difasilitasi secara berkesinambungan, untuk bisa terlibat dan semangat dalam berkompetisi, baik ditingkat lokal, nasional maupun internasional.

8) Program Penghargaan atas Prestasi mahasiswa. Adanya program pemberian penghargaan selain membangkitkan semangat berkompetisi dan rasa diakui serta dihormati, program ini juga bisa menjaga semangat kompetisi yang sudah ada, lebih-lebih bisa meningkatakannya. Bimbingan Dosen dalam berkompetisi. Jaminan adanya bimbingan dari prodi maupun dari perguruan tinggi untuk mahasiswa yang akan berkompetisi, menambah optimisme mahasiswa dan percaya diri mahasiswa.

\section{IMPLIKASI}

Dari uraian di atas, dapat diambil kesimpulan tentang strategi peningkatan kemandirian belajar mahasiswa Pendidikan Bahasa Arab Universitas Islam Riau adalah sebagai berikut; 1) Menggunakan pendekatan Student Centred learning (SCL) dalam pembelajaran, 2) Menggunakan pendekatan Net-centric dalam media pembelajaran, 3) Membangun kesadaran mahasiswa tentang kemandirian belajar secara ber-kesinambungan, 4) Menggunakan aplikasi E-learning yang mampu mendorong dan menstimulus mahasiswa melakukan kemandirian belajar, 5) Melakukan koordinasi antar Dosen Tetap Prodi Studi (DTPS) dalam perumusan Rencana Pembelajaran Semester (RPS) untuk mata kuliah inti prodi, 6) Menciptakan Lingkungan bahasa Arab, 7) Mengadakan program reward (penghargaan) atas prestasi yang diraih mahasiswa, 8) Adanya bimbingan dosen untuk mahasiswa yang akan berkompetisi.

\section{REFERENSI}

Asrori, I. (2012). Menuju Pembelajaran Bahasa Arab Yang Lebih Memandirikan ( Maha ) Siswa Yang Lebih Memandirikan ( Maha) Siswa. Naskah Pidato Pengukuhan Guru Besar.

Hariadi, B. (2004). Strategi Manajemen. Bayu Media Publising.

Mukhlis, M., \& Tohir, M. (2019). Instrumen Pengukur Creativity And Innovation Mathematic Skills Mahasiswa pada. 1, 65-73.

Punaji, S. (2013). Metode Penelitian Pendidikan dan Pengembangan. Kencana.

Ridha, M. (2018). Heutagogi Dan Arah Pendidikan $4.0 \quad$ Kita. https://tinyurl.com/yyms4ts9

Risdianto, E. (2019). Analisis Pendidikan Indonesia di Era Revolusi Industri 4 . o. April, 0-16.

Ristekdikti. (2018). Pendidikan Tinggi: Kesiapan SDM Profesional dan Berdaya Saing Era Industri 4.0.

Samin, S. M. (2019a). Heutagogy Approach for the Teaching of Arabic Language in Islamic Education at Universitas Islam Riau. ALSINATUNA, 5(1), 20-29. 
Samin, S. M. (2019b). Kemandirian Belajar bagi Pembelajar Bahasa Arab di Tingkat Perguruan Tinggi di Era 4.0. Prosiding Pertemuan Ilmiah Internasional Bahasa Arab, 613-618. Saproni. (2017). Pendidikan Kemandirian dalam Islam. Sport Area, 1(2), 61-69. Saproni, S. (2018). Leadership Mentality in Indonesia, $\mathrm{s}$ PTKIS Internationalization. Proceedings International Conference BKSPTIS 2018., 155-164.

Sugiyono. (2014). Metode Penelitian Kualitatif dan Kuantitatif dan $R \& D$. Alfabeta.

Wahab, M. A. (2015). Pembelajaran Bahasa Arab Di Era Posmetode. ARABIYAT: Jurnal Pendidikan Bahasa Arab Dan Kebahasaaraban, 2(1), 59-74. https://doi.org/10.15408/a.v2i1.1519

Zubaidah, S. (2018). Mengenal 4C: Learning and Innovation Skills untuk Menghadapi Era Revolusi Industri 4.0. 2nd Science Education National Conference, April, 1-18. https://www.researchgate.net/publicat
ion/332469989_Mengenal_4C_Learn ing_and_Innovation_Skills_untuk_M enghadapi_Era_Revolusi_Industri_40 $-1$ 